\title{
Stakeholder involvement in adaptive goose management; case studies and experiences from Norway
}

\author{
Ingunn M. Tombre ${ }^{1}$, Einar Eythórsson ${ }^{2} \&$ Jesper Madsen $^{3}$ \\ ${ }^{1}$ Norwegian Institute for Nature Research, Arctic Ecology Department, The Fram Centre, N - 9296 Tromsø, Norway; \\ e-mail: ingunn.tombre@nina.no \\ ${ }^{2}$ Norwegian Institute for Cultural Heritage Research, The Fram Centre, N - 9296 Tromsø, Norway \\ ${ }^{3}$ Aarhus University, Department of Bioscience, Arctic Research Centre, C.F. Møllers Allé 8, DK - 8000 Aarhus C, Denmark
}

\begin{abstract}
Two Svalbard-breeding goose populations, the pink-footed goose Anser brachyrhynchus and the barnacle goose Branta leucopsis, have, over the last decades, increased in numbers and expanded in distribution. At springstaging sites in Norway, conflicts with agriculture are significant as the geese feed on cultivated fields, with negative consequences for the farmers. In the present paper we give an overview of relevant stakeholders in these gooseagriculture conflicts and share some of our experiences when involving stakeholders and users in a dynamic and adaptive process. The paper demonstrates how researchers can engage in the management process at different levels, in order to facilitate a process towards an adaptive co-management in an environment of conflicting interests. The framework described may be used for threatened bird species and situations where there are conflicts between wildlife stakeholders such as management agencies, conservation interests, hunting and agriculture.
\end{abstract}

Key words: Pink-footed goose; Barnacle Goose; adaptive management; stakeholder involvement

\section{INTRODUCTION}

Most of the arctic-breeding western Palaearctic goose populations have increased considerable over the last decades (Madsen et al. 1999; Fox et al. 2010). Their use of cultivated land has increased and conflicts with agriculture have escalated, especially at the spring staging sites (van Roomen \& Madsen 1992). One population that has almost doubled over the last decade is the Svalbard-breeding Pink-footed Goose Anser brachyrhynchus (80 000 individuals in 2012; Madsen et al. 1999; Madsen \& Williams 2012; unpublished data). Another Svalbard-breeding goose species, the Barnacle Goose Branta leucopsis, has also increased with a triplication from 1970s to present (33000 individuals in 2012) but with only a small rate of increase over the last decade (Hall 2011; Mitchell et al. 2010). Both species have stopover sites in Norway on their way to their breeding grounds in Svalbard (Figure 1). The Pink-footed Goose winters in Belgium, The Netherlands and Denmark. In early spring they depart from Denmark for their arctic breeding grounds, and their use of their main spring-staging sites in Norway, in Nord-Trøndelag in central Norway and Vesterålen in North Norway, is of vital importance for their breeding success and survival (Madsen 2001; Madsen et al. 2002, Figure 2). The Barnacle Goose spends the winter in the UK and migrates via stopover sites in Helgeland and Vesterålen in North Norway (Prop et al. 1998; Black et al. 2007; Tombre et al. 2008), where the latter is a relatively new site in spring (Tombre et al. 2010; Shimmings \& Isaksen 2012, Figure 2).

In the present study our focus is at two of these staging sites, Nord-Trøndelag and Vesterålen, where conflicts between geese and farmers are pronounced. When the geese forage on cultivated fields, they may affect farmers who may experience crop damage from goose grazing. An increasing number of geese and associated agricultural conflict call for an effective management and close collaboration between research, wildlife and agricultural authorities, as well as various stakeholders' organisations. As damage, and the dissatisfaction among farmers increases, the engagement of farmers' associations and agricultural authorities at different levels intensifies. The environmental protection authorities also become involved as their responsibility is to manage the geese at a sustainable level, which is of interest for bird watchers' organisations, environmental groups and hunting associations. The Pink-footed Goose is a quarry species, and at present an international management plan is in its implementation phase (Madsen \& Williams 2012). In order to mitigate these conflicts, a balanced approach where stakeholders and users are involved will be appropriate and beneficial. In two ongoing research projects we focus on these two goose populations and their interactions with the various stakeholders. It represents a system where the involvement of stakeholders, in an adaptive process, is highly appropriate as it will mitigate the conflicts if the stakeholders agree on the questions being asked 
Table 1. An overview of the stakeholders involved in the conflicts between agriculture and spring staging geese (Pink-footed Geese and Barnacle Geese) in Norway. Also indicated is the status of the stakeholders; whether they are represented in a reference group (for a research project) where the involvement of stakeholders is relevant.

\begin{tabular}{|c|c|c|c|}
\hline Stakeholder & Institution & Level & $\begin{array}{l}\text { Represented } \\
\text { in reference } \\
\text { group }\end{array}$ \\
\hline Goose & $\begin{array}{l}\text { The Norwegian Ornithological Society }{ }^{1)} \\
\text { (Birdlife Norway) }\end{array}$ & Regional & Yes \\
\hline Environment & $\begin{array}{l}\text { The Directorate for Nature Management } \\
\text { The County Governor }{ }^{2} \text { (Dept. of Environment) } \\
\text { Municipality }{ }^{3)}\end{array}$ & $\begin{array}{l}\text { National } \\
\text { Regional } \\
\text { Local }\end{array}$ & $\begin{array}{l}\text { No } \\
\text { Yes } \\
\text { Yes }\end{array}$ \\
\hline \multirow[t]{3}{*}{ Agriculture } & $\begin{array}{l}\text { Norwegian Agricultural Authority } \\
\text { The County Governor }{ }^{2} \text { ) (Dept. of Agriculture) } \\
\text { Municipality }\end{array}$ & $\begin{array}{l}\text { National } \\
\text { Regional } \\
\text { Local }\end{array}$ & $\begin{array}{l}\text { No } \\
\text { Yes } \\
\text { Yes }\end{array}$ \\
\hline & $\begin{array}{l}\text { The Norwegian Farmers' Union }{ }^{1)} \\
\text { Norwegian Association of Farmers } \\
\text { and Smallholders }^{1} \text { ) }\end{array}$ & $\begin{array}{l}\text { Regional } \\
\text { Regional }\end{array}$ & $\begin{array}{l}\text { Yes } \\
\text { No }\end{array}$ \\
\hline & Landowners' association/farmers & Local & Yes \\
\hline Recreational & $\begin{array}{l}\text { The Norwegian Society for the Conservation } \\
\text { interests of Nature/Friends of the Earth Norway }{ }^{4)}\end{array}$ & & No \\
\hline Hunting & $\begin{array}{l}\text { The Norwegian Association of } \\
\text { Hunters and Anglers }{ }^{1)}\end{array}$ & Regional & Yes \\
\hline
\end{tabular}

1) Organised both at the national, regional and local level

2) Two counties involved in the study, Nord-Trøndelag in Central Norway and Nordland in North Norway

3) The municipalities involved in the study.

Nord-Trøndelag: Steinkjer, Inderøy, Levanger and Verdal

Nordland (Vesterålen): Sortland, Andøy, Hadsel and Øksnes

4) Two municipalities are represented in the reference groups: Levanger and Steinkjer

and the methods to answer these (Lee 1999; Berkes et al. 2003; Armitage et al. 2009). In an adaptive co-management process, management and learning take place simultaneously. Adaptive management is an appropriate approach when the system is changing in response to environmental conditions and management actions (Williams 2011). As a response to the rapid changes during the last decade, increasing goose numbers and their site-use expansion, a subsidy scheme for agriculture has been established in Norway (in 2006, Eythórsson \& Tombre 2013, Tombre et al. 2013). In order to keep up with a continually changing situation and to alleviate conflicts, updated information and flexibility are needed for such learning-based management (see Cundill \& Fabricius 2009).
In the ongoing goose projects at the stopover sites in Norway, we investigate how an adaptive organisation and co-management can be developed in order to alleviate the conflict between geese and farmers. We evaluate the prerequisites for such a system, and develop models that may be used by stakeholders. One type of statistical model, a species distribution model, predicts the probability of goose distribution and may be used as a basis for a subsidy scheme, assisting managers to distribute compensation to the farmers in the most affected areas. We have developed the first generation of such a model to prioritise the subsidy scheme (Jensen et al. 2008), and a more general model including scenario building is currently under development. A model for prediction of optimal hunting practice in autumn 
is also under development. An international flyway management plan for Pink-footed Geese has recently been launched, and one of the aims is to reduce the conflicts with agricultural interests (Madsen \& Williams 2012). There are several ways to alleviate the conflicts, and more goose-friendly agricultural practice has been proposed as one initiative. A reduction in population size may also reduce the conflict level, and in the international plan a regulation of the population size is addressed by defining a population target. Regular autumn hunting is the only available option for this purpose. At present, as the population is the above the agreed level (60000 individuals), the bag size should be increased and the organisation of the hunting practice should be optimised. Hence, an optimal hunting model will be useful for stakeholders, not only because more geese can be shot following the recommendations but also because strategies to minimise crippling rates will be highlighted (this is another goal of the international flyway plan). The stakeholder involvement approach in the implementation of these research projects is especially helpful in these processes as the development of deliverables is specifically designed for the users/ stakeholders.
In the present paper, we describe the adaptive processes in the ongoing research projects in a conflict system involving geese, farmers and other relevant stakeholders. We describe the relevant stakeholders in these goose-agriculture conflicts and share some of our experiences regarding the adaptive processes with stakeholders and users. The paper demonstrates how researchers can engage in the management process on local, regional, national and international levels, in order to facilitate a process towards an adaptive co-management in an environment of conflicting interests. Most of the European goose populations are increasing (Madsen et al. 1999; Fox et al. 2010), but the framework described here may also be used for threatened bird species and situations where there are conflicts between wildlife stakeholders such as management agencies, conservation interests, hunting and agriculture.

\section{MATERIAL AND METHODS}

Goose observations at the two spring staging sites, Nord-Trøndelag and Vesterålen, have been conducted

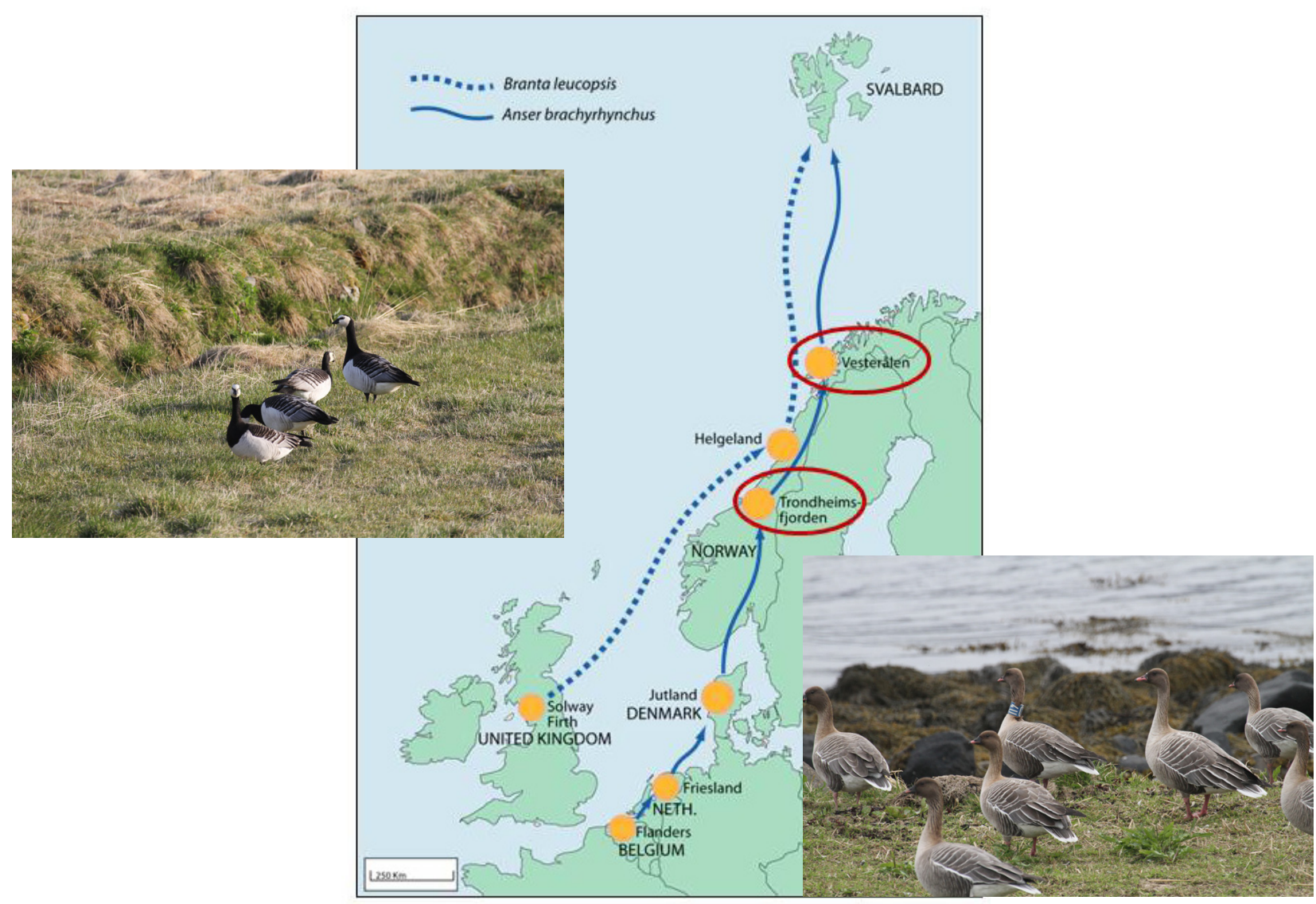

Figure 1. The two goose populations in the study, the Pink-footed Goose and Barnacle Goose, and their flyways. Orange dots are main wintering and spring staging sites, and red circles illustrate the study areas. 


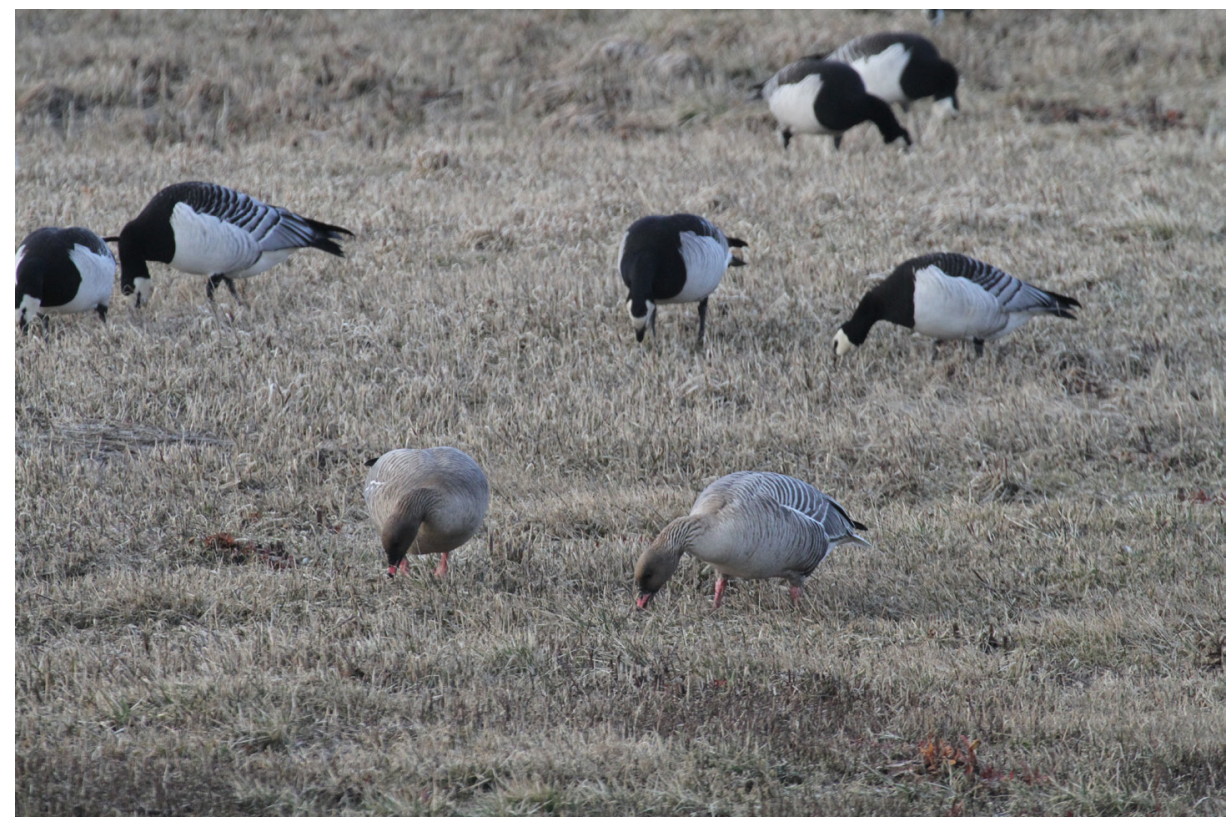

Figure 2. Pink-footed Geese (foreground) and Barnacle Geese spring-staging in North Norway (Photo: Ingunn M. Tombre).

by the project team and co-workers for more than two decades (see Tombre et al. 2008, 2010; Madsen \& Williams 2012 for an overview of relevant references). In-depth interviews of several stakeholders have been conducted in both regions in 2004, 2007 and 2011/2012 (Vesterålen; Eythórsson 2005; unpublished data, Nord-Trøndelag; Søreng 2008; unpublished data). The geese feed primarily on cultivated private land, a situation that makes communication with farmers and landowners an important part of the field activity. This, along with formal and informal meetings with involved parties, has been an important source of information. The meetings have ranged from private visits to persons representing a stakeholder organisation or user group, to meetings initiated either by local/regional environmental protection authorities or agricultural authorities (Figure 3). At these latter meetings, we, as researchers, have been invited to present our research

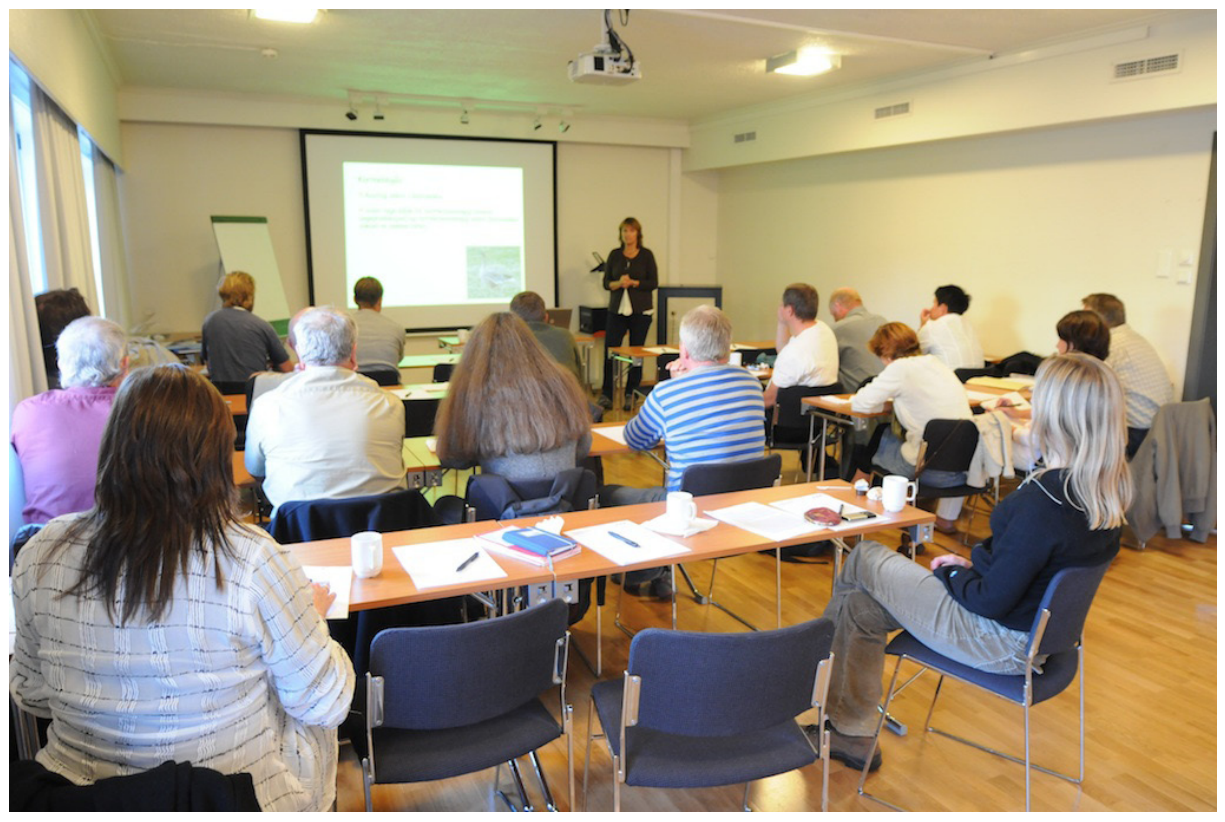

Figure 3. From a meeting with stakeholders at the local/regional level where a new project on goose hunting is launched. 


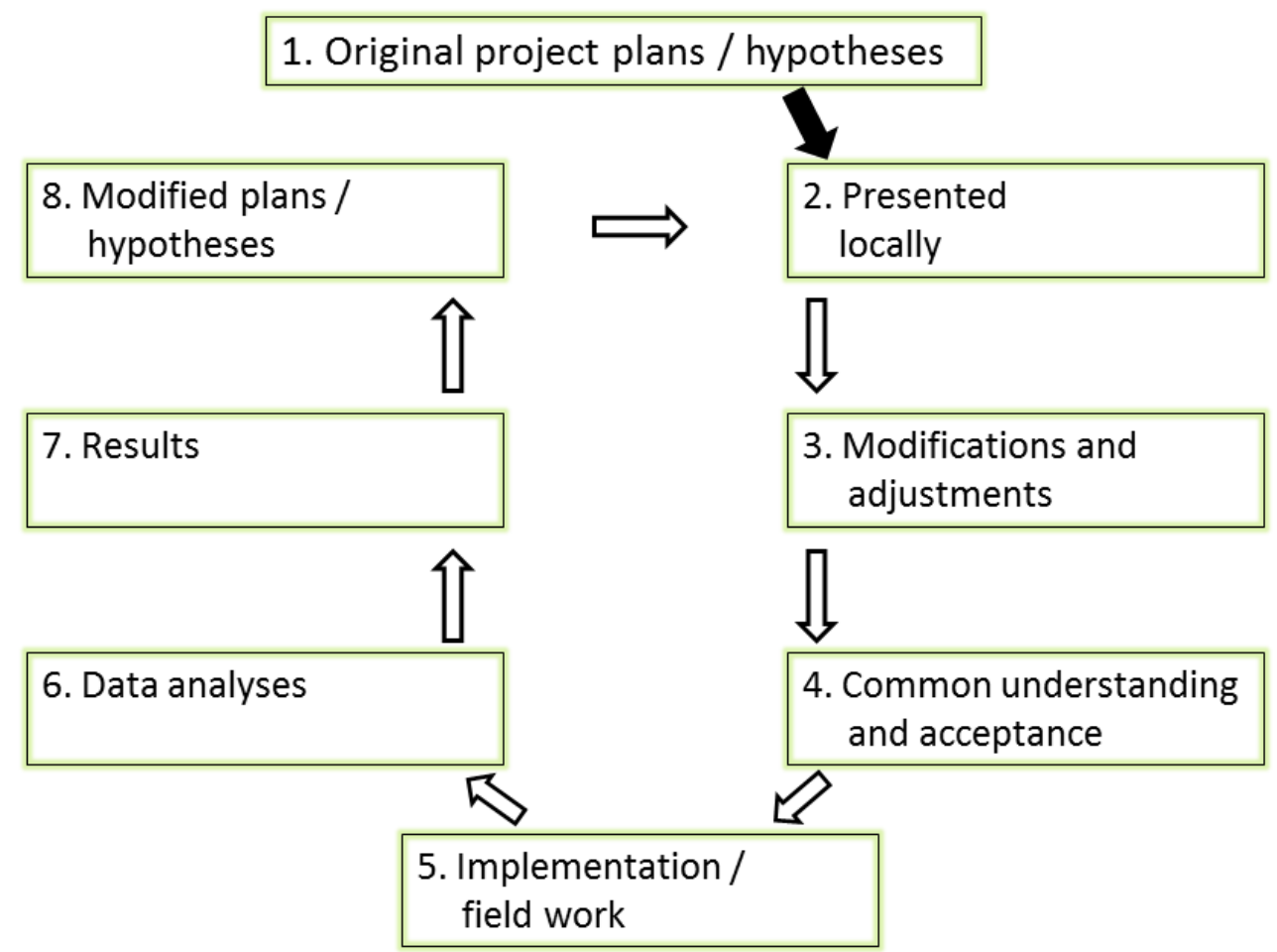

Figure 4. A conceptual model demonstrating the implementation of two research projects focussing on the conflicts between agriculture and spring-staging geese in Norway. The involvement of stakeholders is essential when implementing the projects, and in order to be adaptive and dynamic the process should jump from step eight to step two, rotating several times as the project continues (modified and specifically adapted to the goose-agriculture case after Lindenmayer et al. 2009, 2011).

and results from a neutral researcher's point of view. Through their representation in reference groups the stakeholders are directly involved in discussions about the project and research questions. The research design and approach, however, have basically been decided by the project group in order to maintain an objective independent perspective and scientific standard.

\section{RESULTS}

Geese and agriculture; the stakeholders and users

Table 1 gives an overview of the stakeholders involved in the conflicts between spring staging geese and agriculture at the two stopover sites in Norway, NordTrøndelag and Vesterålen. The different stakeholders represent different levels of their organisation, from local /regional to national level. Some stakeholders have common views of the situation and represent the same interests in the goose-agriculture conflict. Others have conflicting interests and represent different views regarding values and priorities. The Norwegian Ornithological Society ("Birdlife Norway") is the most prominent stakeholder representing goose interests. The environmental stakeholders, in this case representing the goose conservation interests, are the environmental authorities from local/regional (municipality/County) to national scale (the Directorate for Nature Management). From a recreational point of view, The Norwegian Society for the Conservation of Nature/Friends of the Earth Norway is also a relevant stakeholder. Agricultural interests are represented by the agricultural authorities, as well as a series of branches of the farmers' unions/associations and landowners' associations (Table 1). As the pink-footed goose is a quarry species, there are also significant hunting interests. Hunters are basically represented by the Norwegian Association of Hunters and Anglers, but there is an overlap with other stakeholder groups as the typical situation for Norway is that a farmer, a bird watcher and/or a wildlife manager may also be a hunter, representing a group of its' own interests and values.

\section{Adaptive stakeholder involvement in the goose- agriculture conflict}

Regarding the general goose management in Norway, the process towards an active involvement of stakeholders started in the 1990s, as a response to increasing grazing pressure in Vesterålen. The first attempts were unsuccessful (see Eythórsson 2005), but in 2004-2006, 
agricultural interests and wildlife management came to an agreement on a subsidy scheme for compensating farmers for goose grazing (both in North and Central Norway, County Governor of Nordland \& County Governor of Nord-Trøndelag 2005). In a process of conflict solving, it is important to establish a shared understanding of the situation among the involved stakeholders, in terms of population size, extent of damage to agriculture and identification of affected areas. Biological research provided a knowledge platform for this agreement in the form of data series on the staging goose populations, grazing intensity and grazing sites. The active involvement of scientists in the process contributed to a mutual agreement on the knowledge platform for the further process. Most of the disagreement about goals and values, between farmers, hunters, conservationists and managers has also been overcome through dialogue among these stakeholders. Thanks to scientific documentation, conservationists accept and understand the severity of damage to agriculture, while farmers understand the management obligations to maintain a healthy goose population and accept that only legal measures like shooting and scaring, can be applied to reduce grazing damage in spring.

The use of stakeholder involvement in our two research projects in Nord-Trøndelag and Vesterålen is presented in a conceptual model in Figure 4. It illustrates the process from the stage of planning to implementation. The involvement of stakeholders represents everything from informal email correspondence to meetings in the reference group. Such groups were established specifically for each project, and in one of the projects the stakeholders were contacted and the group was established before the project was realised with external funding (see Table 1 for members). In order to be an adaptive and dynamic process, a jump from step eight to step two is necessary, rotating several times as the project continues (Figure 4).

In one of the projects, farmers were directly involved as active collaborators. In order to gather detailed information regarding goose response to scaring, information needed for the goose distribution model, geese were systematically scared off pasture fields following an experimental protocol. Ten farmers participated by scaring the geese as well as logging the response by the geese. In general, farmers chasing geese off their properties are not participants in the subsidy scheme, either because they are reluctant to the arrangement or because their proposal was rejected due to limited funding and other farmers/fields were prioritised. Hence, this co-operation gave us the opportunity to involve potentially sceptical stakeholders in a process where mutual communication and the exchange of experience opened for a constructive activity.

\section{DISCUSSION}

This paper gives an overview of the different stakeholders/users in the goose-agriculture conflict in Norway. A useful framework on how to involve these parties in an adaptive process towards conflict mitigation was also demonstrated. From our experience, such involvement has been absolutely vital for the accomplishment of research projects seeking models that can contribute to a solution to the conflict. These kinds of projects, at the spring staging sites for two goose populations on their way to their breeding grounds in the high arctic in Svalbard, also enable researchers to engage in the management process at different levels to facilitate the process towards an adaptive co-management where there are conflicting interests. By combining biology and social science, the research projects have been able to combine ecological modeling and analysis of various aspects of the conflict. The research activity in itself has appeared to have had an alleviating effect as it has opened for communication and mutual respect among the different stakeholders. The establishment of reference groups has created an arena for round the table discussions and direct dialogue between stakeholder representatives, scientists and management officials.

For the goose-agriculture conflict, there are many advantages with a flexible and efficient system where adjustments are possible. The goose populations involved in the present study have increased and expanded their site-use over the last decades (Madsen \& Williams 2012, Shimmings \& Isaksen 2012), more geese and new sites call for a sound management to mitigate potential conflicts. Also at the breeding grounds in Svalbard, the goose distribution has expanded (Jensen et al. 2008; Tombre et al. 2012). Particularly in situations involving rapid environmental change and potential conflicts, a flexible management and the involvement of stakeholders, are useful. It is, however, a challenging process and, in general, only a few successful cases exists at present (Westgate et al. 2013).

In Norway, the process towards a conflict reduction among geese and agriculture has just begun (Eythórsson \& Tombre 2013, Tombre et al. 2013). The processes described in the present study are examples of how this may be implemented. The framework may be adopted regardless of species, and may be helpful when conflicting parties interact.

Acknowledgements. We thank all the involved stakeholders and users engaged in the goose-agriculture conflicts described in the present study. Without them this work would never have been possible. Financial support was received from the Research Council of Norway, the Directorate for Nature Management, the County Governor of Nordland (Department 
of the Environment), the County Governor of Nord-Trøndelag (Department of the Environment, Department of Agriculture), the Fram Centre in Tromsø and Sortland Municipality. We thank Kari Sivertsen (NINA) for making the map in Figure 1.

\section{REFERENCES}

Armitage, D.R., Plummer, R., Berkes, F., Arthur, R.I., Charles, A.T., Davidson-Hunt, I.J., Diduck, A.P., Doubleday, N.C., Johnson, D.S., Marschke, M., McConney, P., Pinkerton, E. \& Wollenberg, E.K. 2009. Adaptive co-management for social-ecological complexity. Frontiers in Ecology and the Environment 7: 95-102.

Berkes, F., Folke, C. \& Colding, J. 2003. Navigating socialecological systems: building resilience for complexity and change. Cambridge University Press, Cambridge, UK.

Black, J.M., Prop, J. \& Larsson, K. 2007. Wild goose dilemmas. Population consequences of individual decisions in Barnacle Geese. Branta Press, Groningen.

County Governor of Nordland \& County Governor of NordTrøndelag. 2005. Sluttrapport for prosjektet Forvaltning av gjess i Norge - konfliktdempende tiltak (Final report from the project Management of Geese in Norway conflict alleviating measures). County Governor of Nordland, Bodø. (In Norwegian)

Cundill, G. \& Fabricius, C. 2009. Monitoring in adaptive co-management: Towards a learning based approach. Journal of Environmental Management 90: 3205-3211.

Eythórsson, E. 2005. Gjess til besvær. Utfordringer i forvaltningen av ville gåsebestander med utgangspunkt i beitekonflikten i Vesterålen. Norut NIBR Finnmarkrapport 2004-2. (In Norwegian)

Eythórsson, E. \& Tombre, I. M. 2013. Tilskudd til tilrettelegging av beitearealer for trekkende hvitkinngås og kortnebbgås; Erfaringer fra Nord-Trøndelag og Vesterålen. NIKU Rapport 69. (In Norwegian)

Fox, A.D., Ebbinge, B.S., Mitchell, C., Heinicke, T., Aarvak, T. , Colhoun, K., Clausen, P., Dereliev, S., Farago, S., Koffijberg, K., Kruckenberg, H., Loonen, M., Madsen, J., Moijj, J., Musil, P., Nilsson, L., Pihl, S. \& van der Jeugd, H. 2010. Current estimates of goose population sizes in western Europe, a gap analysis and an assessment of trends. Ornis Svecica 20: 115-127.

Hall, C. 2011. An update on the status of geese wintering in Britain and Ireland, 2009/10. Poster at the conference "Waterfowl of Northern Eurasia: Geography, Dynamics and Population Management". Elista, Kalmykia, Russia 24-29 March 2011.

Jensen, R.A., Madsen, J., O'Connell, M., Wisz, M.S. , Tømmervik, H. \& Mehlum, F. 2008. Prediction of the nesting distribution of Pink-footed Geese under a warmer climate scenario. Global Change Biology 14: 1-10.

Lee, K. 1999. Appraising adaptive management. Conserv. Ecol. 3: 3 .

Lindenmayer, D.B. \&Likens, G.E. 2009. Adaptive monitoring: a new paradigm for long-term research and monitoring. Trends in Ecology and Evolution 24: 482-486.

Lindenmayer, D.B., Likens G.E., Haywood, A., Miezis, L. 2011. Adaptive monitoring in the real world: proof of concept. Trends in Ecology and Evolution 26: 641-646.

Madsen, J. 2001. Choice of spring migration strategies by Pink-footed Geese Anser brachyrhynchus and consequences for spring fattening and fecundity. Ardea 89: 43-55.

Madsen, J. \& Williams, J.H. 2012. International species management plan for the Svalbard population of the Pinkfooted Goose Anser brachyrhynchus. AWEA Technol. Rep. No. 48. African-Eurasian Waterbird Agreement, Bonn, Germany.

Madsen, J., Cracknell, G. \& Fox, T. (Eds.) 1999. Goose Populations of the Western Palearctic. A review of status and distribution. Wetlands International Publ. No. 48, Wetlands International, Wageningen, The Netherlands and National Environmental Research Institute, Rönde, Denmark.

Madsen, J., Frederiksen, M. \& Ganter, B. 2002: Trends in annual and seasonal survival of Pink-footed Geese Anser brachyrhynchus. Ibis 144: 218-226.

Mitchell, C., Colhoun, K., Fox, A.D., Griffin, L., Hall, C., Hearn, R., Holt, C., Walsh, A., 2010. Trends in goose numbers wintering in Britain \& Ireland, 1995 to 2008. Ornis Svecica 20: 128-143.

Prop, J., Black, J.M., Shimmings, P., Owen, M. 1998. The spring range of Barnacle Geese Branta leucopsis in relation to changes in land management and climate. Biological Conservation 86: 339-346.

Shimmings, P. \& Isaksen, K. 2012. Overvåking av rastende hvitkinngjess Branta leucopsis langs norskekysten våren 2012. Rapport til Fylkesmannen i Nordland, miljøvernavdelingen \& Herøy kommune, Nordland. (In Norwegian, with English summary)

Søreng, S. U. 2008. Kortnebbgås på rast i et meningslandskap. Beiteproblematikken i Nord-Trøndelag sett fra gårdbrukere og forvaltning. Norut Alta-rapport 2008-1. (In Norwegian)

Tombre, I. M. Eythórsson, E. \& Madsen J. 2013. Towards a solution to the goose-agriculture conflict in north Norway, 1988-2012: the interplay between policy, stakeholder influences and goose population dynamics. PLoS ONE August 8 (8), e71912, 1-7.

Tombre, I.M, Madsen, J., Bakken, J. 2010. Registreringer av rastende gjess i Vesterålen. Resultater fra våren 2010. NINA Report 613. (In Norwegian, with English summary)

Tombre, I.M., Madsen, J., Clausen, P., Prop, J. \& Hanssen, F. 2012: GOOSEMAP: Site-specific information for gjess occurring on Svalbard. http://goosemap.nina.no/ goosemap_eng/Startpage.aspx

Tombre, I.M., Høgda, K.A., Madsen, J., Griffin, L.R., Kuijken, E., Shimmings, P., Rees, E. \& Verscheure, C. 2008. The onset of spring and timing of migration in two arctic nesting goose populations: the Pink-footed Goose 
Anser brachyrhynchus and the Barnacle Goose Branta leucopsis . Journal of Avian Biology 39: 691-703.

van Roomen, M., Madsen, J., 1992. Waterfowl and agriculture: review and future perspective of the crop damage conflict in Europe. Proceedings of the international workshop "Farmers and Waterfowl: Conflict or Coexistence", Lelystad, the Netherlands, 6-9 October 1991. IWRB Special Publication No. 21: 21-32.

Westgate, M. J., Likens, G.E. \& Lindenmayer, D.B. 2013.
Adaptive management of biological systems: a review. Biological Conservation 158: 128-139.

Williams, B.K. 2011. Adaptive management of natural resources - framework and issues. Journal of Environmental Management 92: 1346-1353.

http://aa.usno.navy.mil/ (accessed 29 March 2010).

Received 22 February 2013. Accepted 14 June 2013 Guest editor: Paul Shimmings 